\title{
Stranded Encyclopedias in Eighteenth-Century Sweden: Exploring the Rise of Alphabetical Encyclopedism
}

\author{
Linn Holmberg
}

For a long time, histories of the rise of the modern encyclopedia were mainly histories of publications: chronologies of large-scale, alphabetically organized reference works, successfully completed in one country after another, from the late 1600s onward. ${ }^{1}$ When looking at such chronologies today, they easily convey the idea of a center-to-periphery diffusion. The modern encyclopedia seems to have taken form in prominent publishing centers in Western Europe-in France, England, and the German states-and then slowly spread outward to more peripheral

${ }^{1}$ Robert Collison, Encyclopaedias: Their History Throughout the Ages (New York: Hafner, 1964); Frank A. Kafker, ed., Notable Encyclopedias of the Seventeenth and Eighteenth Centuries: Nine Predecessors of the Encyclopédie (Oxford: Voltaire Foundation, 1981); Frank A. Kafker, ed., Notable Encyclopedias of the Late Eighteenth Century: Eleven Successors of the Encyclopédie (Oxford: Voltaire Foundation, 1994).

\section{Holmberg $(\bowtie)$}

Stockholm University, Stockholm, Sweden

e-mail: Linn.holmberg@idehist.su.se

(C) The Author(s) 2021

L. Holmberg and M. Simonsen (eds.), Stranded Encyclopedias, 1700-2000, New Directions in Book History, https://doi.org/10.1007/978-3-030-64300-3_4 
regions of the continent. The first Swedish and Danish general encyclopedias, for example, were not completed until around the mid-nineteenth century, more than a hundred years after their French, English, and German predecessors. ${ }^{2}$

Yet the geographical expansion and implementation of a new literary practice and the history of its most successful, printed outcomes do not necessarily share the same milestones. Every publication is proceeded by practical work-but not all practical work results in publication. In fact, it may take a long time before it does. This, however, is a matter that has rarely been systematically explored. The multiplication of printed dictionaries in eighteenth-century Europe may be a well-known phenomenon, ${ }^{3}$ but we still lack knowledge about how the practice of making them was established and refined in various regions. In order to gain insights into this development, we cannot rely (solely) on printed works.

The present study is an experimental attempt to explore the early formation of alphabetical encyclopedic practice in Sweden, far from the prominent publishing centers on the European continent. When and why did literate actors in the Swedish kingdom start to make-or talk about making-factual dictionaries? How did their activities relate to discourses and practices on the continent? In order to answer these questions, this chapter will explore a number of stranded encyclopedic projects, detected partly through the contemporary periodical press, partly through archival research. By examining the motivations and circumstances underpinning their initiation and abandonment, the study aspires to produce new insights into the early formation of alphabetical encyclopedism in eighteenth-century Sweden.

${ }^{2}$ Sven Lidman, "Uppslagsboken", in Den svenska boken 500 àr, ed. Harry Järv (Stockholm: Liber, 1983), 329-362; Axel Andersen, Veje til viden: Handbøger og andre informationskilder (Copenhagen: Danmarks Biblioteksskole, 1990), 71-75; Gertrud Petterson, Uppslagsböckerna och världen: Rapport om en pilotundersökning (Lund: Institutionen för nordiska språk, 1997), 6.

${ }^{3}$ E.g., Pierre Rétat, "L'âge des dictionnaires," in Histoire de l'édition française: Le livre triomphant 1660-1830, ed. Roger Chartier and Henri-Jean Martin (Paris: Fayard, 1984), 232-246; Richard Yeo, "Classifying the Sciences," in The Cambridge History of Science: Eighteenth-Century Science, ed. Roy Porter (Cambridge: Cambridge University Press, 2003), 241-266; Marie Leca-Tsiomis, ed., Dix-huitième siècle, special issue: Dictionnaires en Europe, 38, no. 1 (2006); Lynda Mugglestone, "Ranging Knowledge by the Alphabet: The Literature of Categorization and Organization 1700-1830," in $A$ Companion to British Literature: Long Eighteenth-Century Literature, ed. Robert DeMaria et al. (Chichester: Wiley Blackwell, 2014), 207-222. 


\section{Previous Research and Analytical Terminology}

In the 1990s, the historian of ideas Jakob Christensson argued that "enlightened encyclopedism reached remotely located Sweden in the 1770s" when the publisher Carl Christoffer Gjörwell began making a translation of the French Encyclopédie in Stockholm. ${ }^{4}$ The enterprise was left stranded after a decade, but its brief existence nonetheless demonstrated that modern encyclopedic practice had "reached" the Swedish realm long before there were any fully realized publications. In this respect, Christensson's study was pioneering. With the abandonment of Gjörwell's project, however, Christensson concluded that Swedish encyclopedism died and remained "stone dead" until the 1820s-when the first Swedish general encyclopedia appeared in print. ${ }^{5}$ He would not be the last researcher to draw such a conclusion. ${ }^{6}$

Christensson never explicitly defined the term encyclopedism, but the way he used it suggests that he thought of it as making a work imitating the Encyclopédie — or at least, an alphabetically organized general reference work. In other words, the definition excluded the making of specialized factual dictionaries. By the mid-1990s, this was not a controversial exclusion. Throughout the twentieth century-and even today-the idea of generality has been a dominant trend in histories of encyclopedias and encyclopedism. For researchers, the idea has functioned as a glue for linking textual compendia throughout the centuries, turning them into milestones in the human pursuit of "complete knowledge."7 From an eighteenth-century perspective, however, this story did not yet exist, at least not in its present shape. As my study will show, contemporaries

${ }^{4}$ Jakob Christensson, "En upplysningstida encyklopedists uppgång och fall," Lychnos (1993): 110: “denna upplysta encyklopedism nådde på 1770-talet även det avlägset belägna Sverige." From here on, all translations from Swedish to English are my own.

${ }^{5}$ Jakob Christensson, Lyckoriket: Studier i svensk upplysning (Stockholm: Atlantis, 1996), 100: “stendöd."

${ }^{6}$ Christoph Leiska (Buller), "Allgemeines Licht, allgemeiner Gebrauch: Carl Christoffer Gjorwells Projekt einer schwedischen Enzyklopädie (1777-1787)," Leipziger Jabrbuch zur Buchgeschichte 17 (2008): 54.

${ }^{7}$ Seth Rudy, Literature and Encyclopedism in Enlightenment Britain: The Pursuit of Complete Knowledge (London: Palgrave Macmillan, 2014); Robert Fowler, "Encyclopaedias: Definitions and Theoretical Problems," in Pre-Modern Encyclopaedic Texts: Proceedings of the Second COMERS Congress, Groningen, 1-4 July 1996, ed. Peter Binkley (Leiden: Brill, 1997), 10-14; Collison, Encyclopaedias, 2. 
rather perceived factual dictionaries as an essentially "new" phenomenon, typical of their own age. ${ }^{8}$ Moreover, general and specialized factual dictionaries were not considered to belong to fundamentally different categories. In terms of practice, the only difference between compiling a specialized dictionary and a more general one was the workload. In this respect, if we want to understand the rise and geographical expansion of "modern" encyclopedism-i.e., alphabetical encyclopedism-we cannot just consider the making of general reference works.

The present study uses the analytical notion of encyclopedism to denote the practice of compiling information in alphabetically ordered articles, in vernacular factual dictionaries, whether they treat one, several, or all fields of knowledge. The French Encyclopédie was a product of this practice, but not its origin. Encyclopedism is thus short for alphabetical encyclopedism, and encyclopedia synonymous with factual dictionary. Finally, by stranded encyclopedic projects, I refer to all kinds of incomplete efforts to make a factual dictionary, regardless of when the work was interrupted. Consequently, when exploring the rise of alphabetical encyclopedism in eighteenth-century Sweden, I will pay as much attention to unrealized visions and ideas about factual dictionaries as to almost complete manuscripts.

\section{Methods, Sources, And the Structure of the Study}

In terms of method and sources, this study can be described as rather experimental and eclectic. Stranded encyclopedias are not easy to find. There is no convenient catalog of literary enterprises once projected but eventually abandoned throughout the centuries. Consequently, most stranded enterprises are discovered by chance. For those who actively seek stranded projects in the early modern period, however, there are two categories of sources that can be especially helpful: the periodical reports of institutions (e.g., academies, learned societies, monastic congregations, governmental departments, etc.) and the "literary news" sections of journals. Both categories often include notifications of works in progress. When comparing such information to databases of publications, stranded enterprises can be detected. If lucky, archival research leads

\footnotetext{
${ }^{8}$ See the section "Dictionary Discourse in Lärda tidningar (1745-1773)" below in this chapter.
} 
to the discovery of preserved manuscripts. ${ }^{9}$ Another strategy is to first make inventories of manuscripts in archival records, and then proceed to contextualize whatever material is found.

In this study, I have used both methods and types of sources. Yet what follows is not simply an investigation of stranded encyclopedias. In order to historicize and analyze the rise of alphabetical encyclopedism in eighteenth-century Sweden, I have also considered printed works, as well as the emergence of a contemporary discourse about factual dictionaries - about their novelty, nature, proper character, and utility.

The first part of the study takes its place in the world of publishing. Here, I have used the Swedish periodical press for locating early encyclopedic projects, but also to get an idea of how printed factual dictionaries were perceived and discussed as a new genre. At the center of the investigation is the learned journal Lärda tidningar ("Learned News"), printed in Stockholm from 1745 to 1773 by the bookseller Lars Salvius. Going through its 2,700 issues, I have analyzed all accounts relating to factual dictionaries in general, and all notices about domestic factual dictionaries in particular. The first category allowed me to detect changing ideas about the factual dictionary over 28 years. The second category allowed me to identify three stranded encyclopedic projects, whose histories of production I have pursued through additional sources.

The second part of my study leaves the world of publishing for another environment of knowledge production and circulation: the Bureau of Mines - the ministry that controlled the Swedish mining industry and metal processing. Based on extensive archival research, I will here reconstruct the encyclopedic efforts of two mining officials who worked on a dictionary of mining and metallurgy for almost forty years (c. 1743-1787), a period largely coinciding with the publication of Lärda tidningar.

By considering all these activities side by side, I hope to provide new insights into the formation of alphabetical encyclopedism in eighteenthcentury Sweden. Obviously, mine is not a complete inventory, neither of stranded encyclopedic projects nor of discussions about factual dictionaries. Rather it should be read as a pilot study, examining what can be gained from combining sources on early encyclopedic practices and discourses.

\footnotetext{
${ }^{9}$ For an example of this procedure, see Linn Holmberg, The Maurists' Unfinished Encyclopedia (Oxford: Voltaire Foundation, 2017), 14-17, 40-41.
} 


\section{To Begin With: An Overview of EArly Modern Sweden}

Prior to the eighteenth century, there is little trace of alphabetical encyclopedic practice in Sweden. Among scholarly works printed in the seventeenth century, the alphabet is rarely used to organize factual content. Besides a few specialized linguistic lexica, ${ }^{10}$ there are a small number of alphabetized catalogs of flora, fauna, and toponyms. ${ }^{11}$ The records of the National Library and National Archives show no signs of seventeenth-century manuscripts resembling factual dictionaries. Thus, even if many unpublished manuscripts written in the period have been lost, it seems that few (if any) scholars used alphabetical order to structure larger collections of information. Large-scale compilations with universal educational purposes, such as Adelig öfning ("Noble Practice") by the baron Åke Claesson Rålamb (1651-1718), typically had a thematic structure. ${ }^{12}$ However, this trend would change in the eighteenth century. In order to understand why, it is necessary to know a few things about the societal transformations that Sweden underwent in this period.

In the course of the sixteenth and seventeenth centuries, the Swedish empire took control over a large territory around the Baltic Sea, which made it one of the most powerful states in northern Europe. As the inhabitants of the empire spoke Swedish, Danish, Estonian, Finnish, German, Russian, and Latvian (as well as a number of other minor languages and dialects), Latin and French commonly served as the lingua franca of scholars and state officials. When Sweden lost its Baltic provinces during the Great Northern War (1700-1721), the linguistic heterogeneity of

\footnotetext{
${ }^{10}$ E.g., Johannes Loccenius, Lexicon juris sueo-gothici (Stockholm: Keyser, 1651). For an overview of linguistic dictionaries, see Sven Göran Malmgren and Emma Sköldberg, "The Lexicography of Swedish and other Scandinavian Languages," International Journal of Lexicography 26, no. 2 (2013): 117-134; Eva L. Haugen, A Bibliography of Scandinavian Dictionaries (New York: Kraus, 1984); John Considine, Dictionaries in Early Modern Europe: Lexicography and the Making of Heritage (Cambridge: Cambridge University Press, 2008), 235-249; John Considine, Small Dictionaries and Curiosity: Lexicography and Fieldwork in Post-Medieval Europe (Oxford: Oxford University Press, 2017).

${ }^{11}$ E.g., Johannes Franck, Speculum botanicum in quo juxta alphabeti ordinent (Uppsala: Mattson, 1638); Elias Til-Landz, Catalogus plantarum (Åbo: Hansson, 1673); Olof Bromelius, Chloris gothica (Göteborg: Rahm, 1694).

12 Åke Claesson Rålamb, Adelig öfning, 6 vols. (Stockholm, 1690-1694). Rålamb’s work has often been called the first Swedish (thematic) encyclopedia. See Lidman, "Uppslagsboken," 337-338.
} 
the kingdom decreased radically. In the succeeding decades of recovery, stabilizing and promoting the Swedish language turned into a matter of national pride, alongside efforts to advance the domestic economy, arts, sciences, and manufacturing. After the death of Charles XII (1682-1718), Sweden was ruled by a National Assembly with representatives from the four estates (the Nobility, the Clergy, the Burghers, and the Peasantry). In this period, known as the Age of Liberty (1718-1772), the national and international book trade expanded. ${ }^{13}$

Compared to France, England, and the German states, book production in Sweden developed at a slower rate. The first printing shop in Sweden was founded in Stockholm in 1484, fourteen years after the first establishment in Paris, and only four years after the first in London. By the early 1740s, however, the French and English capitals had close to fifty printing shops, while Stockholm still only had eight. Most were run by uneducated artisans who primarily printed religious literature. Until the 1740s, it was also quite complicated to procure books in Sweden. There was no general bookshop that offered titles from multiple printers, so each book had to be bought from the person printing it. Those who wanted foreign literature either had to engage a traveling acquaintance to bring books back home, or procure it from a university, a book auction, or one of the German merchants in Stockholm who were authorized to sell foreign literature. ${ }^{14}$ In this regard, even though there were certainly well-educated, affluent individuals in Sweden who had the means to procure some of the first great factual dictionaries of the late seventeenth century-such as the works of Moréri, Bayle, Furetière, or Corneille-they were not easily accessible to a wider literate audience.

A man who would play a central role in transforming the Swedish book market was Lars Salvius (1706-1773). Not only would he start the first general bookshop and lending library in Stockholm and Sweden as a whole, providing books and journals from multiple domestic and foreign

${ }^{13}$ Merry E. Wiesner-Hanks, Early Modern Europe, 1450-1789 (Cambridge: Cambridge University Press, 2013), 352-353.

${ }^{14}$ Anna-Maria Rimm, "Böckernas vägar: Den svenska bokhandelns import av utländska böcker 1750-1800," Sjuttonhundratal 8 (2011): 139-155; Erik Hamberg, “Olof Knös och 1700-talets lärda samlarkultur: Studier kring förmedling och samlande av böcker i Sverige under den gustavianska tiden" (PhD diss., University of Gothenburg, 1985), 122123; Anita Ankarcrona, Bud på böcker: Bokauktioner $i$ Stockholm 1782-1801 (Edsbruk: Akademitryck, 1989), 20, 27; Henrik Schück, Lars Salvius: Minnesteckning (Stockholm: Norstedt, 1929), 75-78, 130. 
printers, but he also launched one of the first Swedish learned journals. ${ }^{15}$ In this capacity, he would become an important mediator for factual dictionaries published on the continent; partly by importing, selling, and lending them, partly by writing about their utility. This makes his business a valid starting point for the investigation at hand.

Born into a well-educated family, Salvius studied at the universities of Åbo and Uppsala in the 1730s and then pursued a law career at the Board of Trade (Kommerskollegium). In 1739, he became the first (unpaid) notary of the newly-founded Swedish Academy of Sciences, a position that he left after only a year. ${ }^{16}$ In 1742 , his life took a new turn when he married the widow of a book printer. Despite not belonging to the printer's guild, he managed to take over the business. As a well-connected and well-educated outsider, he would soon enforce several reforms on the book trade, which eventually made his business the biggest in the country. ${ }^{17}$

In 1745, Salvius launched the journal Lärda tidningar, modeled after continental predecessors such as the Journal des savants, although in a more modest format. Over 28 years, it appeared in roughly 2,700 issues of four pages each, in which literary news were arranged according to the city of origin. The content was either provided by Salvius' personal correspondents, submitted by readers and authors, or translated and modified from accounts in foreign learned journals by Salvius himself. In this regard, Lärda tidningar became part of a European communication channel. ${ }^{18}$

In the mid-1740s, Lärda tidningar was not the only Swedish periodical to communicate learned content, but it was the first to focus exclusively on literary news and to combine a national and international outlook. ${ }^{19}$ Due to these characteristics, this is where one finds some of the

${ }^{15}$ Schück, Lars Salvius, 130-134, 142-156.

${ }^{16}$ Schück, Lars Salvius, 35-36, 54.

${ }^{17}$ Schück, Lars Salvius, 87-101, 108, 120-134; Rimm, "Böckernas vägar," 141.

${ }^{18}$ Schück, Lars Salvius, 173-189; see also Ellen Krefting, Aina Nøding, and Mona Ringvej, eds., Eighteenth-Century Periodicals as Agents of Change: Perspectives on Northern Enlightenment (Leiden: Brill, 2015); Hans-Jürgen Lüsebrink and Jeremy D. Popkin, eds., Enlightenment, Revolution and the Periodical Press (Oxford: Voltaire Foundation, 2004).

${ }^{19}$ Before the launch of Lärda tidningar, the Royal Society of Sciences in Uppsala (Vetenskaps-Societen, founded in 1710) gathered notices about Swedish publications in their Acta (printed from 1720), written in Latin and targeting a foreign audience. A 
first sustained attempts to describe literary trends abroad, while simultaneously relating them to domestic conditions. Therefore, Lärda tidningar can provide valuable insights into how-and when-news about the multiplication of factual dictionaries on the European continent reached a wider Swedish audience, how this phenomenon was interpreted, and how it could be made into a national concern. Thus, before examining the first reports about Swedish encyclopedic projects in the making, we shall take a look at emerging discourse about factual dictionaries in general.

\section{Dictionary Discourse in Lärda Tidningar (I745-I773)}

In 28 years, Lärda tidningar reviewed close to fifty printed factual dictionaries. ${ }^{20}$ Most were foreign, and most were French. Besides these reviews, comments on the dictionary genre occurred in advertisements (for new works arriving to Salvius' bookstore), notifications of forthcoming publications, international calls for subscribers, and letters to the editor. Together, these accounts form a discursive landscape, whose characteristic undergoes certain changes over time.

Comments about the overall multiplication of dictionaries in eighteenth-century Europe are present throughout the whole period, from the early $1750 \mathrm{~s}$ onward. In the earlier years, however, no terminological distinction is yet made between linguistic and factual dictionaries. They are all called lexica (in Swedish, lexica or ordböcker). This can be seen in one of the first elaborate accounts of the dictionary genre, appearing in 1751 :

The last hundred years, which have made such remarkable progress in the arts and sciences, have had great help and benefit from the many lexica [my italics] that have been issued on all sciences in general, and on individual arts and sciences in particular. Entire learned societies as well as

Swedish version, entitled Tidningar om de lärdas arbeten, appeared 1742-1743. It only covered domestic publications. Some general newspapers included bits of literary news, among them Post- och inrikes tidningar from the early 1700s onward, and Stockholms weckoblad (1745-1779). The French-speaking Stockbolm Gazette (1742-1758) mostly concerned news from abroad. See Schück, Lars Salvius, 173-175; Per Rydén and Karl Erik Gustafsson, A History of the Press in Sweden (Gothenburg: Nordicom, 2010), 13, 28-34.

${ }^{20}$ The following conclusions are based on a complete inventory of Lärda tidningar, executed by the author in 2017 . 
individual writers have worked on them, and with great diligence and drudgery collected the best from multiple authors, and then inserted it into a work in alphabetical order. This has greatly relieved the pressure on those who study certain arts and sciences, $[\ldots]$ since they find summarized in one work, everything they would have retrieved from [many] others. The French in particular have compiled and published such lexica. ${ }^{21}$

Even though the described works are simply called lexica, the surrounding descriptions make it clear that the writer means dictionaries with factual content, gathering and summarizing the most essential parts of the "best" books. In this respect, the factual dictionary is portrayed as a shortcut to learning. By emphasizing the dominance of French works, the lack of similar Swedish ones becomes apparent.

In 1759, a review employs for the first time a specific term for distinguishing factual dictionaries from linguistic dictionaries: real-lexicon. At this point, the anonymous writer (probably Salvius) strongly emphasizes the novelty of the genre. While linguistic lexica had been around for centuries, the real-lexicon was characteristic of the present age:

In our fathers' time, we knew little or nothing of other lexica than those serving to instruct in certain languages. But since the end of the last century, so many real-lexica [my italics] have been published that almost every science has its own, if not several. ${ }^{22}$

In the 1760s, the French term dictionnaire emerges as synonym for real-lexicon, sometimes Swedified as dictionair (singular) or dictionairer

${ }^{21}$ Lärda tidningar, no. 80 (1751): 319-320, review of colonel Jacob Eggers, Dictionnaire militaire (1751): "Närwarande hundrade åratal, som gjort så märkeliga framsteg i konster och wetenskaper, har icke haft liten hjelpreda och förmon av de många lexica [my italics], som blivit utgifne, så wäl öfwer alla wetenskaper i gemen, som öfwer någon wiss konst och wetenskap i synnerhet. Häruppå hafwa dels hela lärda samfund gemensamt, dels enskildte personer arbetat, hwilka med mycken flit och möda samlat tilhopa det bästa utur åtskilliga auctorer, och sedan infört det samma uti et werk efter alfabetisk ordning. Detta har mycket lättat deras möda, som lagt sig på wissa konster och wetenskaper [...] efter de funnit uti et werk sammanfattat, alt hwad de utur de förra kunnat hämta. Fransoserna hafwa i synnerhet arbetat ut sådana lexica och dem i dagsljuset utgifvit."

${ }^{22}$ Lärda tidningar, no. 40 (1759): 160, review of Prosper Marchand, Dictionnaire historique (1758-1759): "I wåra fäders tid wisste wi föga eller alsintet af andra lexica, än sådana, som tjänte att inhämta wissa språk. Men sedan närmare mot slutet af det nästförflutne seculum äro så många real-lexica [my italics] utgifne, at nästan hwar wetenskap har sit egit, om ej flera." 
(plural). From this decade onward, reviews of foreign factual dictionaries increasingly show that readers had begun to expect certain things from these books. Reviewers declare that works of this kind should "unite conciseness and thoroughness," 23 "enlighten reason and refine the heart," "examine the full body of a subject, not overstep its boundaries, and describe all things treated with philosophical care." 24 When a work ignored these fundamental principles, it could be dismissed as a mere "collection of remarks in alphabetical order, [rather] than a Dictionnaire." 25

Normative statements like these, concerned with the constitution and production of a "proper" factual dictionary, can be described analytically as a discourse about alphabetical encyclopedism. Interestingly enough, in Lärda tidningar, this discourse fundamentally takes shape around specialized dictionaries rather than general ones. A clear majority of the dictionaries that are reviewed treat one or a few areas of knowledge. Somewhat surprisingly, but illustratively, there is not one word about the Parisian Encyclopédie in the entire 1750s. The first notice occurs in October 1762, shortly after the volumes of plates began appearing in Paris. Nevertheless, the way the anonymous writer describes the Encyclopédie at this point reveals that he was well-familiar with "the Dictionary [Dictionnairen] whose continuation is so much desired by all learned Europe," and which would "bestow eternal glory upon its makers." 26 On most other occasions, however, general factual dictionaries are more likely to be criticized for their plumped-up content and for making knowledge less accessible rather than the opposite. ${ }^{27}$ Moreover, in 1766, Salvius

${ }^{23}$ Lärda tidningar, no. 49 (1767): 196: "kårthet och grundelighet förenade."

${ }^{24}$ Lärda tidningar, no. 18 (1771): 72: “uplysa förståndet och förbättra hjärtat”, “utföra sitt ämne i hela dess widd, icke gå utom dess gränser, och förnämligast med philosophisk lag-granhet beskrifwa de saker han wille afhandla."

${ }^{25}$ Lärda tidningar, no. 18 (1771): 72: “en samling af anmärkningar i alphabetisk ordning, [snarare] än en Dictionnaire."

${ }^{26}$ Lärda tidningar, no. 79 (1762): 316: "Dictionnairen, hwars fortsättning hela den lärde Europa så mycket mer önskar", "banar tillika åt sina uphofsmän en odödelig ära."

${ }^{27}$ This would also be the main argument of the Uppsala professor Johan Ihre, who in 1774 criticized general factual dictionaries like the Encyclopédie, but praised specialized factual dictionaries. See Krister Östlund, "Johan Ihres kritik mot den franska encyklopedin: Reaktion mot en påstådd kulturell urartning," Sjuttonhundratal 2 (2005): 32. 
explicitly argued that specialized dictionaries were more useful to society since more people could afford them. ${ }^{28}$

From the late 1740s onward, two Swedish works that could be described as factual dictionaries were actually printed. The first appeared in 1748, three years after the launch of Lärda tidningar. It was a mythical-historical lexicon with descriptions of gods, creatures, rites, and kingdoms in ancient literature. ${ }^{29}$ The compiler, Wilhelm Anders Wennerdahl (1709-1753), was a teacher at the gymnasium in Linköping. ${ }^{30}$ The same year he published it, Lärda tidningar announced its appearance but offered no characterization beyond its title. At this early point, there was no recognition that Wennerdahl's work could be seen as part of a new genre emerging in Europe. ${ }^{31}$

Eight years later, a second dictionary appeared. It was a lexicon of householding and farming, compiled by Carl Carleson (1703-1761), a high official of the Chancery Board (Kanslikollegium) and member of the Academy of Science. ${ }^{32}$ Lärda tidningar waited two years to notify its readers about the new publication, but this time, the notification echoed sentiments expressed in reviews of foreign dictionaries in the preceding years. The author was thus praised for gathering information from the best books and for arranging it in alphabetical order, making it easily retrievable for readers. The journal described the preface as "beautiful" and called the lexicon the most comprehensive work of its kind. ${ }^{33}$

Not long afterward, Lärda tidningar began reporting on similar projects in progress.

${ }^{28}$ Lärda tidningar, no. 22 (1766): 86-87.

${ }^{29}$ Wilhelm Anders Wennerdahl, Lexicon mythico-historicum, eller kort och tydelig beskrifning (Linköping: Biörckegren, 1748).

${ }^{30}$ Wilhelm Fredrik Palmblad, "Wennerdahl, Wilhelm Anders," in Biographiskt lexicon öfver namnkunnige svenska män (Uppsala: Wahlström, 1852), vol. 20, 164-165.

${ }^{31}$ Lärda tidningar, no. 51 (1748): 203-204.

${ }^{32}$ Carl Carleson, Hushålls-lexicon (Stockholm: Wildiska tryckeriet, 1756); Bertil Boethius, "Carl Carleson," in Svenskt biografiskt lexikon (Stockholm: Riksarkivet, 1927), vol. 7, 420, accessed May 12, 2020, https://sok.riksarkivet.se/sbl/artikel/16399.

${ }^{33}$ Lärda tidningar, no. 62 (1758): 89-91. 


\section{Glimpses of Stranded Projects}

In the 1750s, Lärda tidningar started to include notifications about forthcoming publications. On three occasions, such notifications concern factual dictionaries. In the end, none of them were published. It is uncertain when and why they were abandoned. Besides the reports in Lärda tidningar, few if any related materials have been preserved. Still, these glimpses of stranded projects through the lens of Lärda tidningar are informative. They indicate what kind of actors took an interest, early on, in making factual dictionaries, what settings they were initiated in, how they were motivated, and what audiences they targeted.

\section{A Rural Lexicon in Åbo}

The first report comes from the Royal Academy of Åbo, in Finland (at the time part of the Swedish kingdom). Founded in 1640, it counted as one of the Swedish universities and played an important role in educating priests, state officials, medical doctors, and military officers. Since the end of the Great Northern War, the educational activities at the Academy had been dominated by interest in economic and scientific progress. By the mid-1750s, under the presidency of professor Pehr Kalm (1716-1779), students were encouraged to make inventories of natural resources in the surrounding regions and present suggestions for how to put them to the most efficient use. ${ }^{34}$

During the autumn of 1757, Lärda tidningar reported on several such suggestions discussed at the Academy of Åbo. ${ }^{35}$ Earlier the same year, a vicar named Abraham Indrenius had presented a dissertation under the supervision of professor Kalm. The dissertation argued that priests could and should play a crucial role in the advancement of the Swedish economy. Inventories in the surrounding regions suggested that the rural population did not understand that aggressive deforestation

${ }^{34}$ Bo Lindberg, "Utilism och upplysningen: Exemplet Åbo," in Upplysningens miljöer: ett nordiskt perspektiv, ed. Gunnar Broberg (Lund: Lund University, 1994), 34-42; Martti Kerkkonen, "Pehr Kalm," in Svenskt biografiskt lexikon (Stockholm: Riksarkivet, 19731975), vol. 20, 598, accessed May 12, 2020, https://sok.riksarkivet.se/Sbl/Presentation. aspx?id=12334.

${ }^{35}$ Notices occur in several issues between August and December: Lärda tidningar (1757), no. 60, 237-240; no. 62, 246-248; no. 74, 295-296; no. 77, 305-308; no. 86, 341-344; no. 87, 357-348, no. 93, 371-372; no. 94, 375-376. 
and discharges from manufacturing damaged the environment. Moreover, distrustful of outsiders, they refrained from alerting the proper authorities when they came across mineralogical deposits on their lands. Ignorant of botany, zoology, and entomology, they had no idea how to handle infestations of crops. All of these situations, and others like them, affected the rural economy in a negative way. According to Indrenius, the best way to change the behavior of the peasants was to go through prieststhe only authorities they trusted. He suggested that priests could educate their congregations at weddings, funerals, baptisms, and other gatherings. However, since priests had little time to undertake studies in mineralogy, agriculture, botany, medicine, or mathematics, they themselves needed some kind of educational tool. ${ }^{36}$

A few months later, another priest in the Indrenius family-Eric Indrenius-presented a proposal for such a tool. In a Latin dissertation, again supervised by professor Kalm, he argued that it was necessary to compile a rural economical lexicon (lexicon oeconomicum rusticum). He even presented a detailed plan for its execution. The lexicon would be written for priests, but adapted to the educational needs of peasants. A work of this kind could potentially treat everything from agriculture, mineralogy, and metallurgy, to medicine, economy, and mathematics. To start with, he suggested a limited focus on natural history and civil architecture. ${ }^{37}$

Analytically speaking, what Eric Indrenius proposed was a factual dictionary, a real-lexicon. It was supposed to summarize useful knowledge in order to educate and change behavior and practices, not just correct the way the rural population talked. As an inspiration, he explicitly mentioned Jacques Savary des Bruslons' Dictionnaire universel de commerce (first printed in 1723), a work that had already served as a source for several encyclopedic projects in France. ${ }^{38}$

\footnotetext{
${ }^{36}$ Abraham Indrenius, Enfaldiga tanckar wisande hwad en präst kan bidraga till oeconomiens uphjelpande (Åbo: Merckell, 1757), 1-16.

${ }^{37}$ Eric Indrenius, De constitutione et utilitate lexici oeconomici rustici (Åbo: Merckell, 1757), 2-10.

${ }^{38}$ Indrenius, De constitutione, 2; Ryuji Kojima, "Aux sources de l'Encyclopédie: Les éditions du Dictionnaire universel de commerce utilisées par les encyclopédistes," Recherches sur Diderot et sur l'Encyclopédie 45 (2010): 153-159; Holmberg, The Maurists' Unfinished Encyclopedia, 182-184. See also the chapter of Hans-Jürgen Lüsebrink in the present volume.
} 
When Lärda tidningar reported on Eric Indrenius' dissertation in early 1758, the rural lexicon was portrayed as already being in progress. The work was to include information on all tasks related to life and work on the countryside, especially information on plants and animals that could be of use or harm. It would also treat civil architecture in order to "teach countrymen how to best and most efficiently build fine houses while sparing the woods as much as possible." Yet, this was just the beginning. According to Lärda tidningar, Indrenius promised that he would treat "the rest" another time. ${ }^{39}$

No rural lexicon ever appeared in Indrenius' (or Kalm's) name. There are no known manuscripts that fit the profile. How far the work progressed before it was stranded is unknown. Still, the fact that a project of this magnitude was proposed at all shows that the $i d e a$ of the factual dictionary as a powerful educational tool-a shortcut to learning-had taken root. After all, Indrenius was targeting an illiterate, rural population, through priests.

\section{A Factual Dictionary of Seamanship in Karlskrona}

The next report about a burgeoning encyclopedic project derives from the town of Karlskrona, the seat of the Royal Swedish navy in the south of Sweden. In 1765, lieutenant Johan Fredrik Dalman (1726-1809)a sailor and teacher at the local navy cadet school-published a "Draft for a Sea Lexicon": Uthast till ett sjö-lexicon. ${ }^{40}$ When Lärda tidningar reviewed the work in 1766, Salvius praised it as the first Swedish dictionary devoted to technical "art-words" (konst-ord), a genre that the French had been perfecting for almost a century. Salvius was therefore delighted to finally see a Swedish work devoted to the same cause, especially since "we do not even have a complete register of general words yet, and of art-words close to nothing." 41 Clearly, Salvius did not count Carleson's householding lexicon (1756) as part of this category.

${ }^{39}$ Lärda tidningar, no. 62 (1758): 248: “undervisa lantmännen huru han bäst och gagneligast skal bygga fina hus, och tilika i görligaste måtto spara skogen," "de öfriga lemnar han til en annan gång."

${ }^{40}$ Johan Fredrik Dalman, Utkast till ett sjö-lexicon, hwarutinnan de ord som egenteligen brukas wid amiralitetet och till sjös, kårteligen blifwa förklarade (Örebro: Lindh, 1765).

${ }^{41}$ Lärda tidningar, no. 22 (1766): 86-87: “[wi] icke en gång hafwa fullständiga ordaregistrer öfwer allmänt brukeliga ord, och af konst-ord knapt äge något.” 
Dalman had collected words employed at the Admiralty in Karlskrona and at sea. The definitions were concise. In the preface, however, the author emphasized that it would be more useful with more comprehensive descriptions and illustrations, all of which "should appear in a more comprehensive sea lexicon shortly." By starting with a draft, he wanted to encourage others to come forth with "useful criticism and suggestions for improvements." 42 This strategy had been used previously by other dictionary compilers on the continent. For example, Antoine Furetière and Pierre Bayle both published small-scale drafts of their dictionaries a few years before their main works appeared. ${ }^{43}$ Dalman thus suggested that a bigger enterprise - an illustrated factual dictionary — was in the pipeline, and he called for his peers to get involved. Lärda tidningar repeated his words and emphasized that the author was "saving material" for a more comprehensive work. ${ }^{44}$

As a well-educated, well-traveled, and well-connected man with artistic skill, Dalman was certainly a promising candidate for compiling an illustrated dictionary of seamanship. Born into a family of naval officers, he had originally pursued a career within the Admiralty in Karlskrona. In 1747 he was elected a junior fellow of the Academy of Science. ${ }^{45}$ The following year, he accompanied the Swedish East India Company to Canton, serving as the Academy's diarist. During the trip, he made detailed maps of coastlines, cities, and buildings. ${ }^{46} \mathrm{He}$ also collected and brought back exotic plants and animals to the botanist Carl Linnaeus (1707-1778), for which the latter long remained grateful. ${ }^{47}$ In 1763 ,

${ }^{42}$ Dalman, Utkast till ett sjö-lexicon, "Företal," 2: "torde framdeles uti et fullkomligare Sjö-Lexicon utkomma," "nyttiga critiquer som andra förbättringar."

${ }^{43}$ E.g., Antoine Furetière, Essais d'un dictionnaire universel (Amsterdam: Desbordes, 1685); Pierre Bayle, Projet et fragmens d'un dictionnaire critique (Rotterdam: Leers, 1692).

${ }^{44}$ Lärda tidningar, no. 22 (1766): 87.

${ }^{45}$ E. W. Dahlgren, Kungliga svenska vetenskapsakademin: Personförteckningar 17391915 (Stockholm: Almqvist \& Wiksell, 1915), 178.

${ }^{46}$ Archives of the Royal Academy of Science (KVA), Dalman, Johan Fredrik, "Dagbok uppå Konglige Vetenskaps Academiens befalning, hållen under resan från Giötheborg till Canton och hem, 1748-1749," accessed May 12, 2020, http://www.ub.gu.se/samlin gar/handskrift/ostindie/dokument/document.xml?id=187.

${ }^{47}$ Transcriptions of Linnaeus letters to Dalman can be found in Theodor Magnus Fries, ed., Bref och skrifvelser af och till Carl von Linné: Afd. 1. D. 5, Bref till och frän svenska enskilda personer - Bäck (1756-76), C och D (Stockholm: Ljus, 1911), 327-330; Fries, 
Dalman was recruited to the newly founded cadet school in Karlskrona, where he worked as a teacher until $1777 .{ }^{48}$ Consequently, it was during this period-at the cadet school—-that Dalman compiled his Draft, probably with the needs of his students in mind. Accordingly, this would also have been the place where he continued his encyclopedic work-if he ever did.

Dalman never published a factual dictionary of seamanship. There are no dictionary manuscripts preserved in his name, nor any other sources that mention the project. Yet, interestingly enough, the archives of the Royal Society of Naval Sciences in Karlskrona have preserved a partial manuscript of a Swedish dictionary of seamanship, written by an anonymous compiler. Large parts seem to have been translated from French, but the draft draws on several sources and thereby counts as a work of its own. ${ }^{49}$ Whether Dalman had something to do with it is unclear, but someone at the Admiralty in Karlskrona must have. The manuscript is not dated, but the paper, ink, and handwriting all suggest that it was compiled in the eighteenth century. ${ }^{50}$ Here again, we get just a glimpse of encyclopedic activity, this time manifesting itself in the navy.

\section{An Economical "Dictionnaire" in Stockholm}

The third and last report in Lärda tidningar about a domestic encyclopedic project derives directly from Lars Salvius himself. In 1768, the journal officially announced the forthcoming publication of "a new

ed., Bref och skrifvelser af och till Carl von Linné: Afd. 1. D. 2, Skrifvelser och bref till K. Svenska vetenskaps-akademien och dess sekreterare (Stockholm: Ljus, 1908), 132-133.

${ }^{48}$ I thank AnnaSara Hammar for providing me with this information from Swedish Naval Officers 1700-1800 (database under construction), based on Hjalmar Börjesson, Biografiska anteckningar om örlogsflottans officerare 1700-1799 (Stockholm: Generalstabens litografiska anstalt, 1942). See also Willhelm Sjöstrand, Kadettskolan i Karlskrona 1756-1792 (Karlskrona: Tidskrift i sjöväsendet, 1937).

${ }^{49}$ Archives of the Royal Society of Naval Sciences (KÖMS), Karlskrona, "Ord-bok som innehåller swensk öfwersättning såwäl uti skepps-byggeriet som sjömanskapet förekommande fransyska konst-ord, samt sådana sjötermer af samma språk, hvilka uti avisor, reseoch lefwernes-bekrifningar förekomma" (40 pages). I thank the archivist Andreas Nilsson at KÖMS for locating this manuscript.

${ }^{50}$ This is further confirmed by the fact that the last registered owner of the manuscript was Pierre Augustin Le Canu, a naval officer who died in a shipwreck in 1801. See Naval Archives (NA), Stockholm (War Archives), officers list (rulla på amiralitetsstaterna), $\mathrm{SE} / \mathrm{KrA} / 0500-0503 / 0503 / 036 / 1 \mathrm{~b} / 56$ (1801). 
Dictionaire oeconomique, or a new and complete economical lexicon" by Salvius' publishing house. ${ }^{51}$ In a three-page announcement, the journal proudly promised that the dictionary would present "facts, inventions, information, observations, [and] guidance and instructions" regarding an impressive range of practical endeavors: agriculture, silviculture, husbandry, fishing, hunting, gardening, bee-keeping, natural history, popular medicine, surveying, engineering, carpentry, mining, metal making, and several other arts and crafts. Furthermore, the dictionary promised to provide descriptions of the climate and natural resources of all regions in Sweden. It would even transcribe all legal documents regulating the rural economy, thereby making them available to all. ${ }^{52}$ In short, it was a massive enterprise.

According to the announcement, Salvius planned to edit the work himself. Lärda tidningar promised that the dictionary would be based on the best writings by domestic and foreign authors, but also contain the fruits of "confirmed experience." By this, Salvius meant knowledge and skill in the possession of common people but not yet made public. He therefore invited everyone with useful information to contact him, preferably by sending a letter to his bookstore. Those who did would be listed as contributors in the dictionary's preface and thus "with due recognition $[\ldots]$ be remembered." 53

By 1768 , such a call for collective engagement was surely an effect of the growing international reputation of the French Encyclopédie. As Lärda tidningar had concluded six years earlier that "eternal glory" would be bestowed upon the contributors to the Encyclopédie for their achievements, it is possible that Salvius hoped to inspire Swedish readers with similar thinking. Contribute-and be famous! In this regard, a lot had changed in ten years. Compared with the householding lexicon published by Carleson in 1756, Salvius was now visualizing a dictionary that contained more than just summaries of authoritative texts and the experience of one man. Like the lexicon projected in Åbo in 1757, Salvius’ enterprise reflected a wider effort to take stock of Swedish resources and

${ }^{51}$ Lärda tidningar, no. 93 (1768): 370: "en ny Dictionaire oeconomique, eller et nytt och fullständigt Oeconomiskt lexicon."

${ }^{52}$ Lärda tidningar, no. 93 (1768): 370: “rön, upfinningar, upgifter, anmärkningar, anledningar och efterrättelser."

${ }^{53}$ Lärda tidningar, no. 93 (1768): 372: “igenom egen förfarenhet bekräftadt", “med med tilbörlig ärkänsla $[\ldots]$ skal ihogkomas.” 
skill. But while the priests in Åbo had pointed out the ignorance of the rural population as a problem, Salvius made no such statement. On the contrary, he stressed that the dictionary would treat subjects of interest to all estates and invited everyone to contribute. Even though Salvius obviously expected to be contacted by people who could read and write, his call for contributions did not explicitly exclude anyone.

Lärda tidningar promised that the enterprise was well-advanced and that the public would be informed as soon as it was ready for printing. Until then, samples of the work-in-progress could be consulted in Salvius' bookshop. ${ }^{54}$ However, by the time of Salvius' death in 1773, no economical dictionary had been issued by his publishing house. In the obituary, his publishing assistant Samuel Loenboem mentioned that his employer had left behind a number of manuscripts, including a "comprehensive collection of $[\ldots]$ descriptions of the regions of Sweden." 55 Since none of Salvius' manuscripts have been preserved, we do not know if they included material for the dictionary. ${ }^{56}$ Faced with a lack of sources, one can only speculate about what happened to the project. Regardless, as the main editor of a journal appearing twice a week-and one of the most active publishers of scientific literature in Sweden-Salvius would not have been the last person failing to realize an encyclopedic ambition because of an overwhelming workload.

In the subsequent decades, readers of other Swedish journals and magazines would have been able to observe the rise and decline of several similar projects. In 1777, the bookseller Johan Christopher Holmberg (1743-1810) announced the forthcoming publication of yet another "economical Dictionnaire, or a general, complete householding lexicon." 57 This time, four volumes were actually published between 1779 and 1792, but the work did not make it past the letter $\mathrm{C}$ before the author, Johan Fischerström (1735-1796), died. ${ }^{58}$

${ }^{54}$ Lärda tidningar, no. 93 (1768): 372.

${ }^{55}$ Lärda tidningar, no. 102 (1773): 407: “widlöftiga samlingar till [...] Swenska landsorters beskrivning."

${ }^{56}$ Schück, Lars Salvius, 202.

57 Stockholms post-tidningar, no. 70 (1777).

58 Johan Fischerström, Nya Swenska economiska dictionnairen, eller försök til et almänt och fullständigt lexicon $i$ den svenska hushallningen och naturläran, 4 vols. (Stockholm: Stolpe, 1779-1792). 
Thus, when, in 1776, the publisher Carl Christoffer Gjörwell (17311811) announced the forthcoming publication of the Encyclopedie, eller fransyskt-spenskt real- och nominal-lexicon ("Encyclopedia, or FrenchSwedish Real- and Nominal-Lexicon") and encouraged readers to subscribe, the literate public in Sweden was no stranger to the concept of factual dictionaries. ${ }^{59}$ Through Lärda tidningar and its successors, journal readers had not only been served news about foreign dictionaries for decades, but also read about countrymen working on Swedish reallexica for the betterment of the nation. Even though these projects had all been left stranded-some, perhaps, barely started-they still demonstrate how the idea and practice of alphabetical encyclopedism was slowly gaining ground in various parts of the Swedish kingdom from the mid-eighteenth century onward.

\section{Encyclopedic Activities in the Bureau of Mines}

Thus far, this study has pinpointed stranded encyclopedias by means of Salvius' Lärda tidningar. Naturally, similar works may have been announced in other Swedish journals as well. But not all encyclopedic projects initiated in the eighteenth century were mentioned in the periodical press. Not all compilers collaborated with a publisher (the figure who commonly informed journal editors of works-in-progress), and not all projects were initiated with a wider audience in mind. Even though the dictionary genre became increasingly commercialized in the latter half of the century, many compilers seem to have been primarily driven by personal motives of knowledge- and data-collection, and only decided to publish their materials at a late stage. ${ }^{60}$ The last encyclopedic project I will deal with is a case in point.

59 Stockbolms lärda tidningar, no. 30 (1776): 115-117.

${ }^{60}$ Such stories can be found in the prefaces to several seventeenth-century factual dictionaries, e.g., Louis Moréri, Grand dictionaire historique, 2 vols. (Lyon: Girin, 1674), vol. 1, n.p.n.; Jacques Savary des Bruslons, Dictionnaire universel de commerce, 3 vols. (Paris: Jacques Estienne, 1723-1730), vol. 1, xv-xvii; Richard Bradley, Dictionarium botanicum, 2 vols. (London: Woodward and Peele, 1728), vol. 1, v. 


\section{A Factual Dictionary of Mining and Metallurgy}

We will now leave the world of publishing and enter the Bureau of Mines (Bergskollegium), where two mining officials worked on a factual dictionary for almost forty years: c. 1743-1787. Their work was initiated and executed in parallel with the expansion of the Swedish book trade, the publication of Lärda tidningar, and the encyclopedic projects reported therein, which opens up the possibility of interesting comparisons. By following the trail of sources, however, we will approach this case backward, starting at the end rather than the beginning.

In 1788, the acclaimed metallurgist Sven Rinman (1720-1792) published an illustrated dictionary of the arts and sciences of mining, entitled Bergwerks lexicon. ${ }^{61}$ It was the first, fully realized factual dictionary in Swedish since the works of Wennerdahl and Carleson in the 1750s, and the first to explain and visualize theoretical aspects of metallurgy, chemistry, and mineralogy, as well as technical know-how relating to forges, blast furnaces, and mine installations. ${ }^{62}$ A contemporary journal praised it as a work that "did not just explain art-words, but concisely treated the science itself." 63 In this respect, it was exactly the kind of specialized, technical factual dictionary that Salvius had called for when praising Dalman's sea lexicon in 1766. Even foreign journalists were positive. The British Analytical Review claimed to be "astonished" that Rinman had "completed, in so short a time, so copious and extensive a work." 64

In the preface, Rinman briefly explained the background of the project. In the beginning of the 1780s, the executive board of the Bureau

${ }^{61}$ Sven Rinman, Bergwerks lexicon, 2 vols. (Stockholm: Carlbohm, 1788-1789).

${ }^{62}$ See Sten Lindroth, Svensk lärdomshistoria: Fribetstiden (Stockholm: Norstedt, 1997), 399; Nils Björkenstam, "Sven Rinman: I bergshanteringens tjänst," in Sven Rinman 17201792: Ett 200-årsminne (Eskilstuna: Eskilstuna museer, 1992), 48; Chris Evans and Göran Rydén, Baltic Iron in the Atlantic World in the Eighteenth Century (Leiden: Brill, 2007), 167n, 277; Chris Evans and Alun Withey, "An Enlightenment in Steel? Innovation in the Steel Trades of Eighteenth-Century Britain," Technology and Culture 53, no. 3 (2012): 546; Göran Rydén, "The Enlightenment in Practice: Swedish Travelers and Knowledge about the Metal Trades," Sjuttonhundratal 10 (2013): 79-80; Hjalmar Fors, The Limits of Matter: Chemistry, Mining, and Enlightenment (Chicago: University of Chicago Press, 2015 ), 99.

63 Stockholms-posten (August 29, 1789): “ej allenast förklarade konst-orden utan ock uti korthet afhandlade sjelfwa wettenskapen."

${ }^{64}$ Analytical Review, or History of Literature, Domestic and Foreign, vol. 7 (MayAugust, 1790): 110. 
of Mines had approached him with a request. They had received the manuscript of a mining lexicon, compiled by the late Anders Robert Bellander (1726-1772) - the former mining inspector of the Sala silver mine. The board wanted Rinman to prepare the manuscript for publication. He accepted the task but quickly realized that the manuscript was too outdated and disordered to be printed. Assisted by his two sons, he revised the whole work over the course of three years. ${ }^{65}$

Still, the preface to the Bergwerks lexicon only told half the story. Archival sources reveal another side. When the board contacted Rinman in 1784, he answered them with a long letter in which he explained that he and Bellander had known each other since their days as young auscultators ("apprentices") at the Bureau of Mines. ${ }^{66}$ It was during these foundational years that the whole idea of making a mining dictionary began.

Before continuing down this path, it is necessary to know a few things about the Bureau of Mines. As one of the eight Swedish collegia or governmental departments, the Bureau of Mines had been in charge of mining and metal processing in Sweden since the mid-seventeenth century. Over time, it had developed an effective, hierarchical structure. At the top, there was an executive board with a president, two councilors, and five assessors. The board controlled a central administration in Stockholm, with some twenty officials and several technical departments. The next level was that of local administrations in twelve mining districts, where mining inspectors (bergmästare) directed practical work in mines and metal-works. At the bottom of the hierarchy were the young apprentices, the so-called auscultators. By sitting in on board meetings, transcribing archival documents, visiting mining districts, and accompanying mining inspectors, they were effectively trained to become the next generation of mining officials. ${ }^{67}$

${ }^{65}$ Rinman, Bergwerks lexicon, vol. 1, "Företal", n.p.n: "hela denne samling måst omarbetas, hvarjemte den til ordrikhet, eller artiklars antal, blifvit ganska mycket förökt."

${ }^{66}$ Archives of the National Museum of Science and Technology (TMA), Stockholm, Rinmans arkiv, FlE:54.

${ }^{67}$ Svante Lindqvist, "Technology on Trial: The Introduction of Steam Power Technology into Sweden, 1715-1736" (PhD diss., Uppsala University, 1984), 95-107; Jacob Orrje, "Mechanicus: Performing an Early-Modern Persona" (PhD diss., Uppsala University, 2015), 85-88. 
According to Rinman, sometime in the early 1740s, the executive board of the Bureau had sent out a circular that urged mining inspectors to collect and report back all the technical words that workers used in their establishments. At this point, Rinman and Bellander were just auscultators, but inspired by the circular, they started working on such a collection together, at first mainly for the sake of their own learning. ${ }^{68}$ After three years, their apprenticeships having ended and their career paths diverging, they parted ways. ${ }^{69}$ In the succeeding decades, they continued their encyclopedic activities under rather contrasting circumstances: Rinman constantly on the move; Bellander stationary.

In 1746, Rinman departed for a study tour abroad. During the trip, he visited several metal manufacturing sites in the Netherlands, Germany, and France, and met with influential metallurgists and chemists in Paris. ${ }^{70}$ Upon his return to Sweden, he was appointed superintendent of blast furnaces (övermasmästare). The assignment kept him on his feet, undertaking endless travels across the country. In 1753, he was elected a fellow of the Academy of Sciences. Six years later, he became the national director of coarse iron and steel manufacturing, a position which involved even more traveling. ${ }^{71}$ Yet during all this time, he kept on collecting "art-words."

In 1765, after some twenty years of work, Rinman delivered the draft of an illustrated "Ironworks Lexicon" to the board of the Bureau. In the accompanying letter, he stressed that he had been working on the manuscript in his spare time since his years of auscultating. He believed that a dictionary of all the arts and sciences of mining would be of great use to apprentices entering the profession, but he possessed "neither the time nor the capacity" to elaborate such a comprehensive manuscript himself. He hoped, nevertheless, that his draft-focused on ironworkswould constitute a well-needed beginning. He did not specify the size

${ }^{68}$ TMA, Rinmans arkiv, F1E:54.

${ }^{69}$ Johan Almquist, Bergskollegium och bergslagsstaterna 1637-1857: Administrativa och biografiska anteckningar (Stockholm: Norstedt, 1909), 168; Bror Erik Olsson, "Sven Rinman," in Sven Rinman 1720-1792, 8.

${ }^{70}$ Marco Beretta, "Rinman, Diderot, and Lavoisier: New Evidence regarding Guillaume François Rouelle's Private Laboratory and Chemistry Course," Nuncius 26 (2011): 355-379; Gösta Bodman, "Sven Rinman's reseanteckningar 1746-47," parts I-III, in Daedalus: Tekniska museets årsbok (Stockholm: Nordiska rotogravyr, 1949-1952).

${ }^{71}$ Björkenstam, "Sven Rinman,” 17-18. 
of the draft in his letter, but it appears to have been nearly finished and practically ready for print. ${ }^{72}$ However, Rinman's lexicon was never published. In fact, it seems to have been completely destroyed. In 1766, a fire broke out in Uppsala, where Rinman and his family lived. The entire house-including the library, mineral collections, and the dictionary manuscript-was burnt to the ground. ${ }^{73}$ After this devastating setback, Rinman seems to have given up on the lexicon. For the next decade, he was deeply involved in experimental steel-testing and technical improvements at several establishments across the country, while he also published books on metal making and the history of iron. ${ }^{74}$

In contrast, Bellander came to lead a much more stationary life. After completing his training, he settled down at the Sala silver mine, the oldest and once most prestigious mining district in the country. There he occupied various positions before eventually reaching the top of the hierarchy in 1761, when he became the local mining inspector. ${ }^{75}$ Unlike Rinman, he never published any scholarly works, nor was he admitted to an academy. Still, for his entire adult life, he kept working on a dictionary of mining and metallurgy — until he suddenly passed away in 1772, only 46 years old. ${ }^{76} \mathrm{~A}$ few years later, his family handed over the manuscript to the Bureau. Eventually, it found its way to Rinman.

What makes this history all the more interesting is that Bellander's dictionary manuscript has actually been preserved at the National Archives in Stockholm. Until recently, this ten-volume collection was believed to be (and is still cataloged as) Rinman's work (see Fig. 4.1). ${ }^{77}$ Upon closer

72 TMA, Rinmans arkiv, F1E:7-8: "Jernwärks-Lexicon.”

${ }^{73}$ Rinman retells this story in a letter dated 1784. See TMA, Rinmans arkiv, FlE:54.

${ }^{74}$ Björkenstam, "Sven Rinman," 16-55; Måns Jansson, "Making Metal Making: Circulation and Workshop Practices in the Swedish Metal Trades, 1730-1775" (PhD diss., Uppsala University, 2017), 81-84; Hjalmar Fors, "Mutual Favors: The Social and Scientific Practice of Eighteenth-Century Swedish Chemistry" (PhD diss., Uppsala University, 2003), 110-111.

75 Almquist, Bergskollegium, 40.

${ }^{76}$ This assertion derives from Rinman himself, which might suggest that he and Bellander stayed in contact, even though there is no preserved correspondence between them. See TMA, Rinmans arkiv, F1E:54.

${ }^{77}$ National Archives of Sweden (RA), Stockholm, Bergskollegiums huvudarkiv, D8:110, "Rinmans Bergwerks lexicon." 


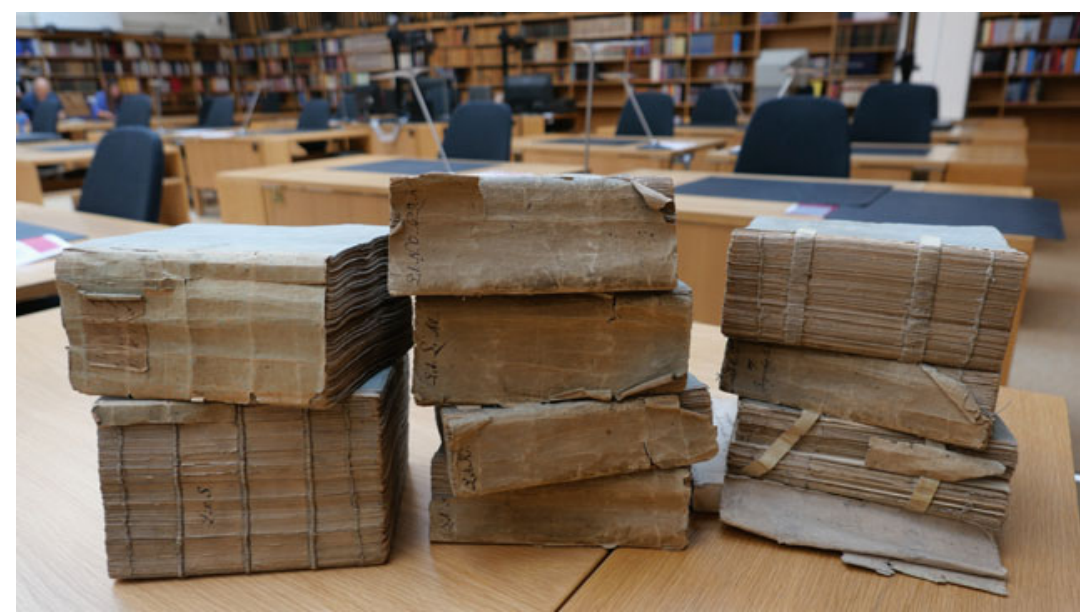

Fig. 4.1 Bellander's ten-volume dictionary manuscript, preserved under the name of Sven Rinman. National Archives of Sweden, Stockholm. Bergskollegiums huvudarkiv, D8:1-10, "Rinmans Bergwerks lexicon." (Photo: Linn Holmberg)

inspection, the handwriting shows that Bellander compiled the main articles, while the margins contain multiple comments and additions from a later date, inserted by Rinman and his two sons (see Fig. 4.2). ${ }^{78}$ Together this unique set of sources-Bellander's manuscript, Rinman's later annotations, and the printed Bergwerks lexicon-offers a rare opportunity to examine the evolution of the dictionary: how Rinman revised Bellander's manuscript, and consequently, how the two mining officials proceeded in their long-independent encyclopedic activities.

While Rinman never had the time to prepare a full dictionary of mining and metallurgy, Bellander clearly had more time at hand. His ten-volume manuscript demonstrates an impressive breadth and depth, although the size of the articles varies considerably. Some are little more than a line, while others occupy fifty pages and include illustrations. At first sight, Bellander's manuscript appears to be rather "complete": the

${ }^{78}$ For comparative material signed by Bellander, see RA, Bergskollegiums huvudarkiv, E2b:12, E2b:16. For comparative material signed by Sven Rinman, see E2a:17. 


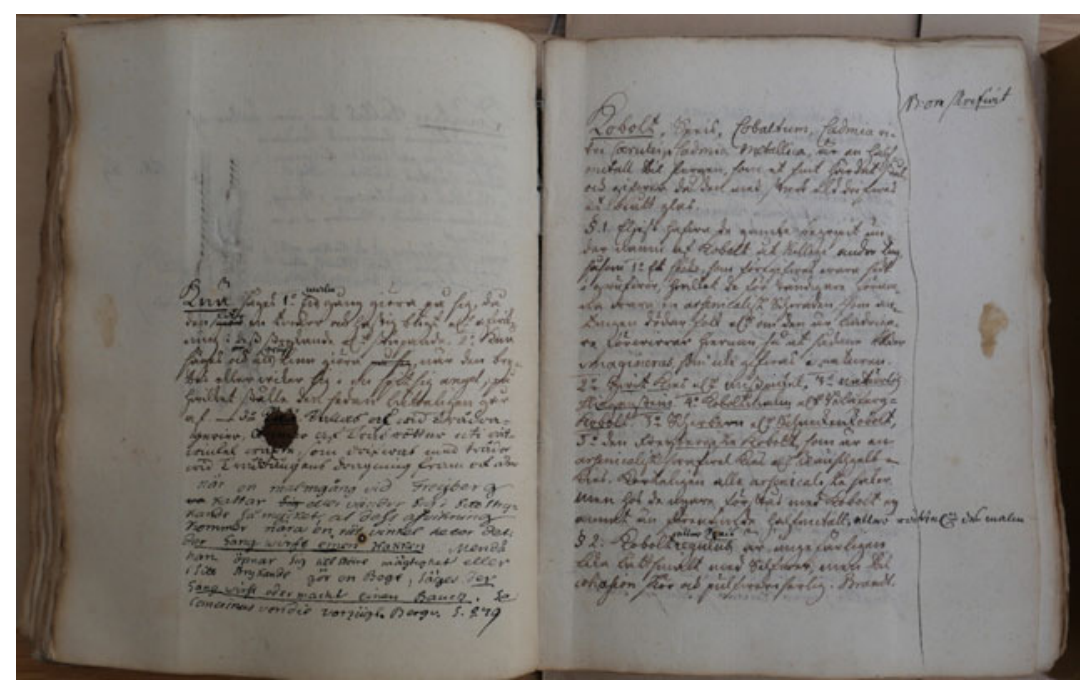

Fig. 4.2 Two pages from Bellander's dictionary manuscript, showing the articles "Knä" and "Kobolt." On the left page, Rinman has written an addition in black ink, just below Bellander's handwriting. On the right page, Rinman has noted "revised" (omskrifivit) in the margin. National Archives of Sweden, Stockholm. Bergskollegiums huvudarkiv, D8:6 (Photo: Linn Holmberg)

ten volumes cover the entire alphabet. ${ }^{79}$ The neat handwriting further suggests that most articles were rewritten at least once (but probably many more times in view of how long he worked on it). Yet none of the volumes exhibit complete alphabetization. ${ }^{80}$ Many sheets contain large blank spaces, which suggests that Bellander was still leaving room for additional keywords at the time of his death. These details reveal that the manuscript was far from being ready for print. Moreover, several articles

${ }^{79}$ RA, Bergskollegiums huvudarkiv, D8:1-10. The collection is ordered as follows: vol. 1 (A), 2 (B), 3 (C-E), 4 (F-G), 5 (H-J), 6 (K), 7 (L-M), 8 (N-R), 9 (S), 10 (T-Ö).

${ }^{80}$ That is, headwords are alphabetized by their first letters, but not by subsequent ones, as complete alphabetization would require. This characteristic of Bellander's manuscript, in combination with the lack of pagination, makes it difficult to locate-and accurately refer to-specific articles within the volumes. 
contain long transcriptions from French and Latin books, without translation. These sections have been neatly rewritten too, as if the compiler was satisfied to leave them that way-at least temporarily.

There is no indication that Bellander was ever in contact with a publisher, nor that he submitted a preliminary draft to his superiors, as Rinman did. ${ }^{81}$ It is thus possible that Bellander's manuscript was not compiled primarily in order to be printed. Rather, it seems that he revised and rewrote sections of his dictionary as part of a learning processas a way of remembering. When Rinman evaluated the manuscript in 1784, he reached the same conclusion. Just as they both had in their younger days, Bellander had kept collecting "whatever he found interesting when reading books," and thus compiled a dictionary mainly for his own learning's sake. ${ }^{82}$

Naturally, one cannot exclude the possibility that publishing crossed Bellander's mind. The manuscript shows that he was a meticulous reader of Lärda tidningar, from which he often transcribed reviews of foreign publications from the $1760 \mathrm{~s}$ onward. ${ }^{83}$ As a result, he was surely no stranger to evolving discourse about the utility of the factual dictionary, as it took shape in the journal. As he died prematurely, Bellander might not have reached the point of actively working toward publication. When Rinman inherited the manuscript, he was explicitly tasked with producing a publication - and he proceeded accordingly.

In his first letter about Bellander's manuscript, addressed to the board of the Bureau in January 1784, Rinman stressed the necessity of defining the proper boundaries for a mining lexicon in order for it to be useful. Bellander had been too inclusive, he thought. Rinman recommended the exclusion of alchemical terminology, medicinal mineralogy, and natural historical accounts without any clear relationship to metal making, such as articles on fossils. ${ }^{84}$

In early 1785, after one year of work, Rinman told the board that he was spending all his waking hours revising the manuscript. The project

${ }^{81}$ Incoming materials were regularly registered in the archives of the Bureau. Although Bellander's name occurs on several occasions, it never does in relation to the production of a dictionary. E.g., RA, Bergskollegiums huvudarkiv, E 2b:12-13.

82 TMA, Rinmans arkiv, FlE:54: "hvad han under böckers läsning funnit märkvärdig."

${ }^{83}$ References to Lärda tidningar are dispersed throughout the volumes, and also occur in Bellander's list of sources consulted, placed in the second volume.

${ }^{84}$ TMA, Rinmans arkiv, F1E:54. 
had turned out to be more demanding than he first thought. He needed to replace outdated sources with more recent ones, move articles to their proper places within the alphabet, and cut-and add-many more accounts than initially expected. ${ }^{85}$ Another year later, in 1786 , he still claimed that the collection needed to be "entirely rewritten, fairly greatly expanded, and explained with many more illustrations." 86 Luckily, he was now receiving intensive help from his two sons, who by then had become mining officials in their own right. Indeed, throughout Bellander's manuscript, the margins are filled with comments like "revised" (omskrifvit), "completely revised" (totalt omskrifvit), or "cut" (går ut). ${ }^{87}$ On several occasions, sections or whole articles have been crossed out, and new information added in different handwritings. All these changes are clearly carried over in Rinman's printed lexicon.

Despite the fact that the two main compilers were men of practice, they compiled quite differently. Bellander based his accounts predominantly on other texts, while Rinman also included observations from his professional experience. ${ }^{88}$ Moreover, in a mining report dated February 1787 , Rinman even described how he had instructed his two sons to go on field trips to mining and smelting sites around the country, in order to collect technical words and information about practical procedures currently in use, all of which was to be included in the lexicon. ${ }^{89}$ These differences in procedure further reinforce the impression that Bellander was using alphabetical encyclopedism primarily as tool for managing information in books. For Rinman, it was also a tool for documenting not-yet recorded practical knowledge, as well as for establishing firmer boundaries around the science of mining, and communicating these boundaries to others. To use the terminology of Lärda tidningar: if Bellander compiled "a collection of remarks in alphabetical order," then Rinman turned it into a proper Dictionnaire. ${ }^{90}$

85 TMA, Rinmans arkiv, FlE:56.

${ }^{86}$ TMA, Rinmans arkiv, F1E:57: "helt och hållet omskrifwas samt ganska mycket tilökas och med många nya ritningar förklaras.”

${ }^{87}$ E.g., RA, Bergskollegiums huvudarkiv, D8:1-5, “Alchemie" (Alchemy), "Kemi" (Chemistry), and "Jern" (Iron).

${ }^{88}$ E.g., Rinman, Bergwerks lexicon, "Garfstål," 578; "Knifstål," 992-993. See also Jansson, "Making Metal Making," 136-137.

${ }^{89}$ TMA, Rinmans arkiv, F1E: 58.

${ }^{90}$ Lärda tidningar, no. 18 (1771): 72. 
However, one should not discount the importance of Bellander's work. In his manuscript, there is a fourteen-page bibliography, which reveals that practically all of his sources were memoirs, treatises, and periodical journals. $^{91}$ In fact, there is only one dictionary in the entire list: Elie Bertrand's Dictionnaire universel des fossiles (1763), which was favorably reviewed by Lärda tidningar in $1764 . .^{92}$ Consequently, over three decades, Bellander completed a formidable task simply in deciding on an appropriate collection of headwords, not to mention in laying the factual foundation for thousands of articles drawn from the literature at hand. In comparison, by the mid-eighteenth century, most French compilers-including contributors to the French Encyclopédie-had access to a great number of factual dictionaries in their own language, from which they could relatively quickly construct a catalog of keywords, and then transcribe, revise, and add factual content. ${ }^{93}$

Thanks to Bellander's manuscript, Rinman did not start from nothing, despite the fact that his own dictionary manuscript had been incinerated eighteen years earlier. He could freely choose what to keep, throw away, revise, and add. Given that the printed preface downplayed the quality of Bellander's work, the Analytical Review could hardly help but be "astonished" that Rinman had "completed, in so short a time, so copious and extensive a work." 94 In reality, the Bergwerks lexicon was only made possible because another mining official had spent thirty years laying the groundwork.

Perhaps this is where we find one of the answers to the question why so many other encyclopedic projects were left stranded in eighteenth-century Sweden. Compiling a vernacular factual dictionary from scratch took time-lots of time. Visions, materials, and physical manuscripts needed to pass through several heads and hands before eventually reaching the printing press.

${ }^{91}$ E.g., RA, Bergskollegiums huvudarkiv, D8:2.

92 Lärda tidningar, no. 33 (1764): 131-132.

${ }^{93}$ See Marie Leca-Tsiomis, Écrive l'Encyclopédie: Diderot, de l'usage des dictionnaires à la grammaire philosophique (Oxford: Voltaire Foundation, 1999); Martine Groult, "Comment commencer une construction? Exemple avec Chambers et Panckoucke dans leur rapport à l'Encyclopédie," in M. Groult, ed., Les encyclopédies: Construction et circulation du savoir de l'antiquité à Wikipedia (Paris: L'Harmattan, 2011); Holmberg, The Maurists' Unfinished Encyclopedia, 162-214.

${ }^{94}$ Analytical Review (1790): 110. 


\section{Summary AND CONCLUSIONS}

This chapter has examined a number of stranded encyclopedic projects in eighteenth-century Sweden, initiated-or at least imagined-from the late 1740s onward. To judge by the absence of factual dictionaries in print and manuscript prior to this decade, it seems likely that alphabetical encyclopedism began to be practiced concurrently with the expanding book trade and with the increasing bureaucratization of Swedish governmental bodies in the decades of recovery following the end of the Great Northern War. The actors involved-teachers, priests, state officials, publishers, sailors, and mining inspectors-moved in and between environments of education, government, commerce, and technical manual work. Their projects for dictionaries either responded to or called for inventories of local knowledge and skills. Bellander and Rinman began collecting technical words after a general call by the board of the Bureau of Mines. Some forty years later, Rinman sent his sons to collect terminology from mining and smelting establishments around the country. Indrenius' rural lexicon was a response to an ongoing mustering of resources and needs in the Finish regions surrounding Åbo. Dalman collected technical words within the Admiralty in Karlskrona and begged his peers to come up with suggestions for improvement. Salvius invited everyone who possessed some kind of useful knowledge to contribute to his economical dictionary. Proceeding and paralleling these attempts, Lärda tidningarthe first Swedish journal of its kind-regularly reviewed foreign factual dictionaries, praised them as shortcuts to learning, and called for similar projects to be initiated in Sweden. Even though it cannot be proven in this study, it is possible that Lärda tidningar's comments on the utility and proper nature of the factual dictionary helped shape attitudes and practices among its readers; that they inspired individuals in various knowledge environments to handle information in new ways, to divide them into keyword-based articles, and arrange them in alphabetical order. Either way, "enlightenment encyclopedism" neither started nor ended with Gjörwell's attempt to make a Swedish Encyclopédie. Before and after, it flared up and died several times, in many places and many minds, and executed by multiple hands.

Two main conclusions can thus be drawn from this study. First, the long perceived "lag" between European centers and peripheries in eighteenth-century encyclopedia production diminishes when we look at stranded projects and not just completed publications. In countries 
like Sweden, where the book market was underdeveloped compared to continental publishing hubs, bringing vernacular factual dictionaries to completion and publication was difficult. The literate audience was smaller, demand was weaker, and there were fewer vernacular publications for compilers to draw on. Consequently, information had to be either translated or obtained directly from professional environments of interests-and then alphabetized. It was hard, unprofitable work that required a great deal of time and engagement. Still, this did not stop people from trying.

Second, it is clear that many of the early encyclopedic enterprises in Sweden were in fact indigenous projects-influenced by the successful structure of (mostly) French factual dictionaries, certainly, but based on local materials and needs. These are interesting findings, since previous research on the rise of modern encyclopedism in Sweden-focusing on the first general encyclopedias completed in the nineteenth centuryhas tended to describe the Scandinavian tradition as an heir to German conversational dictionaries (Konversationslexika), and notably the Brockhaus Enzyklopädie. ${ }^{95}$ When we open up our perspective and consider stranded encyclopedic projects in the eighteenth century, this image changes significantly. Above all, my research here suggests that we should not think about encyclopedias as a genre that was "invented" in one place and then "exported" to others, but rather view alphabetical encyclopedism as a practice gradually taking shape across a vast geographical area, interconnected by the book trade and learned periodicals, which commented on-and thus possibly further stimulated-ongoing literary trends. ${ }^{96}$

Acknowledgements This chapter is a result of the research project "Redefining Scientific Knowledge" (dnr: 2016-03039), financed by the Swedish Research Council (Vetenskapsrådet). The chapter also draws on archival research conducted in 2016, financed by Åke Wibergs Stiftelse.

${ }^{95}$ E.g., Lidman, “Uppslagsboken,” 338-340; Jacob Christensson, “Brockhaus på svenska: P.G Berg och Svenskt konversationslexikon," Biblis 29 (2005): 27-44; Maria Simonsen, "Den skandinaviske encyklopædi: Udgivelse og udformning af Nordisk familjebok \& Salmonsens Konversationslexikon" (PhD diss., Lund University, 2016), 48-64.

${ }^{96}$ This subject is further explored in my new research project, entitled "Dictionary Craze: Transforming Knowledge Across Early Modern Europe," funded by the Swedish Foundation for Humanities and Social Sciences, and part of the Pro Futura Scientia fellowship program at the Swedish Collegium for Advanced Study, Uppsala. 


\section{REFERENCES \\ Archival Resources}

Archives of the National Museum of Science and Technology (TMA), Stockholm.

Rinmans arkiv, F1E: 7-8, 54, 56-58.

Archives of the Royal Academy of Science (KVA), Stockholm.

Dalman, Johan Fredrik. "Dagbok uppå Konglige Vetenskaps Academiens befalning, hållen under resan från Giötheborg till Canton och hem, 17481749." Accessed May 12, 2020. http://www.ub.gu.se/samlingar/handskrift/ ostindie/dokument/document.xml?id=187.

Archives of the Royal Society of Naval Sciences (KÖMS), Karlskrona.

"Ord-bok som innehåller swensk öfwersättning såwäl uti skepps-byggeriet som sjömanskapet förekommande fransyska konst-ord, samt sådana sjötermer af samma språk, hvilka uti avisor, rese- och lefwernes-bekrifningar förekomma." 40 pages.

National Archives of Sweden (RA), Stockholm.

Bergskollegiums huvudarkiv, E2b:12-13, E2b:16, E2a:17, D8:1-10.

Naval Archives (NA), Stockholm.

War Archives, officers list (rulla på amiralitetsstaterna): SE/KrA/05000503/0503/036/1 b/56 (1801).

\section{Printed WORKS}

Almquist, Johan. Bergskollegium och bergslagsstaterna 1637-1857: Administrativa och biografiska anteckningar. Stockholm: Norstedt, 1909.

Analytical Review, or History of Literature, Domestic and Foreign (1790).

Andersen, Axel. Veje til viden: Håndboger og andre informationskilder. Copenhagen: Danmarks Biblioteksskole, 1990.

Ankarcrona, Anita. Bud på böcker: Bokanktioner i Stockholm 1782-1801. Edsbruk: Akademitryck, 1989.

Beretta, Marco. "Rinman, Diderot, and Lavoisier: New Evidence regarding Guillaume François Rouelle's Private Laboratory and Chemistry Course," Nuncius 26 (2011): 355-379.

Palmblad, Wilhelm Fredrik. "Wennerdahl, Wilhelm Anders." In Biographiskt lexicon öfver namnkunnige svenska män, vol. 20: 164-165. Uppsala: Wahlström, 1852. 
Björkenstam, Nils. "Sven Rinman: I bergshanteringens tjänst.” In Sven Rinman 1720-1792: Ett 200-årsminne, 16-55. Eskilstuna: Eskilstuna museer, 1992.

Boethius, Bertil. "Carl Carleson." In Svenskt biografiskt lexikon, vol. 7: 420. Stockholm: Riksarkivet, 1927. Accessed May 12, 2020. https://sok.riksar kivet.se/sbl/artikel/16399.

Bodman, Gösta. "Sven Rinman's reseanteckningar 1746-47," parts I-III. In Daedalus: Tekniska museets årsbok. Stockholm: Nordiska rotogravyr, 19491952.

Bradley, Richard. Dictionarium botanicum. 2 vols. London: Woodward and Peele, 1728.

Bromelius, Olof. Chloris gothica. Göteborg: Rahm, 1694.

Börjesson, Hjalmar. Biografiska anteckningar om örlogsflottans officerare 17001799. Stockholm: Generalstabens litografiska anstalt, 1942.

Carleson, Carl. Hushålls-lexicon. Stockholm: Wildiska tryckeriet, 1756.

Christensson, Jakob. "Brockhaus på svenska: P.G. Berg och Svenskt konversationslexikon," Biblis 29 (2005): 27-44.

Christensson, Jakob. "En upplysningstida encyklopedists uppgång och fall," Lychnos (1993): 109-149.

Christensson, Jakob. Lyckoriket: studier $i$ svensk upplysning. Stockholm: Atlantis, 1996.

Collison, Robert. Encyclopaedias: Their History Throughout the Ages. New York: Hafner, 1964.

Considine, John. Dictionaries in Early Modern Europe: Lexicography and the Making of Heritage. Cambridge: Cambridge University Press, 2008.

Considine, John. Small Dictionaries and Curiosity: Lexicography and Fieldwork in Post-Medieval Europe. Oxford: Oxford University Press, 2017.

Dahlgren, E. W. Kungliga svenska vetenskapsakademin: Personförteckningar 1739-1915. Stockholm: Almqvist \& Wiksell, 1915.

Dalman, Johan Fredrik. Utkast till ett sjö-lexicon, hwarutinnan de ord som egenteligen brukas wid amiralitetet och till sjös, kårteligen blifiwa förklarade. Örebro: Lindh, 1765.

Evans, Chris, and Göran Rydén, Baltic Iron in the Atlantic World in the Eighteenth Century. Leiden: Brill, 2007.

Evans, Chris, and Alun Withey, "An Enlightenment in Steel? Innovation in the Steel Trades of Eighteenth-Century Britain," Technology and Culture 53, no. 3 (2012): 533-560.

Fischerström, Johan. Nya Swenska economiska dictionnairen, eller försök til et almänt och fullständigt lexicon $i$ den svenska hushållningen och naturläran, 4 vols. Stockholm: Stolpe, 1779-1792.

Fors, Hjalmar. "Mutual Favors: The Social and Scientific Practice of EighteenthCentury Swedish Chemistry." PhD diss., University of Uppsala, 2003. 
Fors, Hjalmar. The Limits of Matter: Chemistry, Mining, and Enlightenment. Chicago: University of Chicago Press, 2015.

Fowler, Robert. "Encyclopaedias: Definitions and Theoretical Problems." In PreModern Encyclopaedic Texts: Proceedings of the Second COMERS Congress, Groningen, 1-4 July 1996. Edited by Peter Binkley. Leiden: Brill, 1997.

Franck, Johannes. Speculum botanicum in quo juxta alphabeti ordinent. Uppsala: Mattson, 1638.

Fries, Theodor Magnus, ed. Bref och skrifvelser af och till Carl von Linné: Afd. 1. D. 2, Skrifvelser och bref till K. Svenska vetenskaps-akademien och dess sekreterare. Stockholm: Ljus, 1908.

Fries, Theodor Magnus, ed. Bref och skrifvelser af och till Carl von Linné: Afd. 1. D. 5, Bref till och frän svenska enskilda personer-Bäck (1756-76), C och D. Stockholm: Ljus, 1911.

Groult, Martine. "Comment commencer une construction? Example avec Chambers et Panckoucke dans leur rapport à l'Encyclopédie." In Les encyclopédies: Construction et circulation du savoir de l'antiquité à Wikipedia. Edited by M. Groult, 139-152. Paris: L'Harmattan, 2011.

Hamberg, Erik. "Olof Knös och 1700-talets lärda samlarkultur: Studier kring förmedling och samlande av böcker i Sverige under den gustavianska tiden." PhD diss., University of Gothenburg, 1985.

Haugen, Eva L. A Bibliography of Scandinavian Dictionaries. New York: Kraus, 1984.

Holmberg, Linn. The Maurists' Unfinished Encyclopedia. Oxford: Voltaire Foundation, 2017.

Indrenius, Abraham. Enfaldiga tanckar wisande hwad en präst kan bidraga till oeconomiens uphjelpande. Åbo: Merckell, 1757.

Indrenius, Eric. De constitutione et utilitate lexici oeconomici rustici. Åbo: Merckell, 1757.

Jansson, Måns, "Making Metal Making: Circulation and Workshop Practices in the Swedish Metal Trades, 1730-1775.” PhD diss., Uppsala University, 2017.

Kafker, Frank A. ed. Notable Encyclopedias of the Late Eighteenth Century: Eleven Successors of the Encyclopédie. Oxford: Voltaire Foundation, 1994.

Kafker, Frank A. ed. Notable Encyclopedias of the Seventeenth and Eighteenth Centuries: Nine Predecessors of the Encyclopédie. Oxford: Voltaire Foundation, 1981.

Kerkkonen, Martti. "Pehr Kalm.” In Svenskt biografiskt lexikon, vol. 20: 598. Stockholm: Riksarkivet, 1973-1975. Accessed May 12, 2020. https://sok.rik sarkivet.se/Sbl/Presentation.aspx?id=12334.

Krefting, Ellen, Aina Nøding, and Mona Ringvej, ed. Eighteenth-Century Periodicals as Agents of Change: Perspectives on Northern Enlightenment. Leiden: Brill, 2015. 
Kojima, Ryuji. "Aux sources de l'Encyclopédie: Les éditions du Dictionnaire universel de commerce utilisées par les encyclopédistes," Recherches sur Diderot et sur l'Encyclopédie 45 (2010): 153-159.

Leca-Tsiomis, Marie. ed. Dix-huitième siècle, special issue: Dictionnaires en Europe 38, no. 1 (2006).

Leca-Tsiomis, Marie. Écrive l'Encyclopédie: Diderot, de l'usage des dictionnaires à la grammaire philosophique. Oxford: Voltaire Foundation, 1999.

Leiska (Buller), Christoph. "Allgemeines Licht, allgemeiner Gebrauch: Carl Christoffer Gjorwells Projekt einer schwedischen Enzyklopädie (17771787)," Leipziger Jahrbuch zur Buchgeschichte 17 (2008): 9-57.

Lidman, Sven. "Uppslagsboken." In Den svenska boken 500 år. Edited by Harry Järv, 329-362. Stockholm: Liber, 1983.

Lindberg, Bo. "Utilism och upplysningen: Exemplet Åbo." In Upplysningens miljöer: Ett nordiskt perspektiv. Edited by Gunnar Broberg, 34-42. Lund: Lund University, 1994.

Lindqvist, Svante. "Technology on Trial: The Introduction of Steam Power Technology into Sweden, 1715-1736." PhD diss., Uppsala University, 1984.

Lindroth, Sten. Svensk lärdomshistoria: Frihetstiden. Stockholm: Norstedt, 1997.

Lärda tidningar (1745-1773).

Loccenius, Johannes. Lexicon juris sueo-gothici. Stockholm: Keyser, 1651.

Lüsebrink Hans-Jürgen, and Jeremy D. Popkin, eds. Enlightenment, Revolution and the Periodical Press. Oxford: Voltaire Foundation, 2004.

Malmgren, Sven Göran, and Emma Sköldberg. "The Lexicography of Swedish and other Scandinavian Languages," International Journal of Lexicography 26, no. 2 (2013): 117-134.

Moréri, Louis. Grand dictionaire historique. 2 vols. Lyon: Girin, 1674.

Mugglestone, Lynda. "Ranging Knowledge by the Alphabet: The Literature of Categorization and Organization 1700-1830." In A Companion to British Literature: Long Eighteenth-Century Literature. Edited by Robert DeMaria et al, 207-222. Chichester: Wiley Blackwell, 2014.

Olsson, Bror Erik. "Sven Rinman." In Sven Rinman 1720-1792: Ett 200årsminne, 5-15. Eskilstuna: Eskilstuna museer, 1992.

Orrje, Jacob. "Mechanicus: Performing an Early-Modern Persona." PhD diss., Uppsala University, 2015.

Petterson, Gertrud. Uppslagsböckerna och världen: Rapport om en pilotundersökning. Lund: Institutionen för nordiska språk, 1997.

Rétat, Pierre. "L'âge des dictionnaires." In Histoire de l'édition française, le livre triomphant 1660-1830. Edited by Roger Chartier and Henri-Jean Martin, 232-246. Paris: Fayard, 1984.

Rimm, Anna-Maria. "Böckernas vägar: Den svenska bokhandelns import av utländska böcker 1750-1800," Sjuttonhundratal 8 (2011): 139-155.

Rinman, Sven. Bergwerks lexicon, 2 vols. Stockholm: Carlbohm, 1788-1789. 
Rudy, Seth. Literature and Encyclopedism in Enlightenment Britain: The Pursuit of Complete Knowledge. London: Palgrave Macmillan, 2014.

Rydén, Göran. "The Enlightenment in Practice: Swedish Travelers and Knowledge about the Metal Trades," Sjuttonhundratal 10 (2013): 63-86.

Rydén, Per, and Karl Erik Gustafsson. A History of the Press in Sweden. Gothenburg: Nordicom, 2010.

Rålamb, Åke Claesson. Adelig öfning, 6 vols. Stockholm, 1690-1694.

Savary des Bruslons, Jacques. Dictionnaire universel de commerce. 3 vols. Paris: Jacques Estienne, 1723-1730.

Simonsen, Maria. "Den skandinaviske encyklopædi: Udgivelse og udformning af Nordisk familjebok \& Salmonsens Konversationslexikon." PhD diss. Lund University, 2016.

Sjöstrand, Willhelm. Kadettskolan i Karlskrona 1756-1792. Karlskrona: Tidskrift i sjöväsendet, 1937.

Schück, Henrik. Lars Salvius: Minnesteckning. Stockholm: Norstedt, 1929.

Stockholms lärda tidningar (1776).

Stockholms-posten (1789).

Stockholms post-tidningar (1777).

Til-Landz, Elias. Catalogus plantarum. Åbo: Hansson, 1673.

Wennerdahl, Wilhelm Anders. Lexicon mythico-historicum, eller kort och tydelig beskrifning. Linköping: Biörckegren, 1748.

Wiesner-Hanks, Merry E. Early Modern Europe, 1450-1789. Cambridge: Cambridge University Press, 2013.

Yeo, Richard. "Classifying the Sciences." In The Cambridge History of Science: Eighteenth-Century Science. Edited by Roy Porter, 241-266. Cambridge: Cambridge University Press, 2003.

Östlund, Krister. "Johan Ihres kritik mot den franska encyklopedin: Reaktion mot en påstådd kulturell urartning," Sjuttonhundratal 2 (2005): 30-37. 
Open Access This chapter is licensed under the terms of the Creative Commons Attribution 4.0 International License (http://creativecommons.org/licenses/ by $/ 4.0 /$ ), which permits use, sharing, adaptation, distribution and reproduction in any medium or format, as long as you give appropriate credit to the original author(s) and the source, provide a link to the Creative Commons license and indicate if changes were made.

The images or other third party material in this chapter are included in the chapter's Creative Commons license, unless indicated otherwise in a credit line to the material. If material is not included in the chapter's Creative Commons license and your intended use is not permitted by statutory regulation or exceeds the permitted use, you will need to obtain permission directly from the copyright holder.

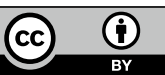

